\title{
Iranian EFL Teachers' Perceptions of Learning Accent
}

Hassan Galbat*, Farhad Fahandezh Sa'adi

Department of English Language, Bandar Abbas Branch, Islamic Azad University, Bandar Abbas, Iran

Corresponding Author: Hassan Galbat, E-mail: hmgalbat@yahoo.com

\section{ARTICLE INFO}

Article history

Received: November 30, 2017

Accepted: January 23, 2018

Published: May 01, 2018

Volume: 7 Issue: 3

Advance access: March 2018

Conflicts of interest: None

Funding: None

\begin{abstract}
Since the appearance of "Audio-lingual Method", the issue of foreign accent has been the focus of many researchers and many teachers attempted to sound as native like as possible to better teach native English accent. The present study attempted to uncover the Iranian EFL teachers' perceptions on accent, the way they viewed their own accent, and how English accent can be improved. Totally 50 male and female teachers with different age range, qualifications, teaching and learning experiences participated in the study. The data of the study were collected using Teachers' Perceptions of Accent Questionnaire developed by the researcher and semi-structured interviews. Based on the analysis performed on the data collected through questionnaires and interviews, it was found that teachers care about learning accent and they considered it valuable and important. They admitted that they have foreign accent to some degree and they did not seem to be happy with foreign accent and were more in favour of native like accent. Regarding the strategies to improve English accent, they mentioned techniques like listening to authentic language, understanding pronunciation rules, and comparing people's accent with their own accent, watching English movies, noticing stress, and pronunciation patterns, imitating, speaking with native people, using books, and recording and monitoring their own speeches.
\end{abstract}

Key words: English Accent, Native Accent, Foreign Accent, Perceptions, Efl Teachersw

\section{INTRODUCTION}

Teachers' beliefs and ideologies have an important role in classroom practices and performances. Beliefs act as filters which determine the procedures and methodologies used by EFL teachers (Borg, 2008, 2009; Farrell \& Patricia, 2005). Many empirical studies have found that teachers' decision-making processes are interwoven with their beliefs (Munby, 1984; Nespor, 1987; Pajares, 1992) and many scholars (e.g. Abelson, 1979; Kagan, 1992; Pajares, 1992) in the field agree with the claim that it plays an important role in shaping one's professional identity. Donaghue (2003), for example, believes that the educational beliefs of teachers affect the way they find personal meaning in terms of their professional identity and direct the teaching method they employ. One of the important aspects of language is accent. The issue of accent is especially of significance in EFL contexts where most of the teachers are non-native speakers of that language. In this regard, the judgments which are possibly made about those individuals who may not have what is called an appropriate accent becomes of significance.

In interpersonal communication everyone inevitably makes judgments about the people they speak with and simultaneously makes an impression on same people. These impressions consist of a vast amount of factors such as physical appearance, non-verbal communication strategies and of course the content of the utterance. But one of the most prom- inent factors that reveals itself immediately is the speaker's manner of pronunciation, intonation and prosodic features: the accent. The main discussion in the previous studies and related research mainly covers attitudes of students towards non-native accents of English, factors influencing foreign accent of non-native speakers, the ways of examining perceptions of non-native accent of languages other than English and the ways of minimizing foreign accent (e.g. Piske, 2001; Boyd, 2003). In countries like Iran where English is taught as a foreign language subject, foreign accent issue emerges naturally among the learners and teachers of English. Despite this fact, unfortunately, the research on this issue is very limited in Iran. The existing studies focused on the subject in terms of identity and foreign accent, pronunciation problems, disadvantages of being a non-native teacher, and reactions to teachers' bad pronunciation (Pourhosein, Gilakjani, 2012; Pishghadam \& Sabouri, 2011; Solhi \& Rahimi, 2013). However, no previous studies, to the best of the present researcher's knowledge, has focused on the teachers' perceptions of learning accents. Therefore, this study is an attempt to fill in this gap in pronunciation and accent issues.

\section{Literature Review}

Given that accent can be easily perceived during oral communication, it plays a crucial role in language learning. 
Therefore, it is one of the significant features of our use of language. Lippi-Green (1993) defines accent as a "no-tight set of prosodic and segmental qualities distributed over geographic and/or social space". A variety of features at different levels make up this construct (e.g. segmental features such the phonological arrangement of vowels and consonants, namely, pronunciation, prosodic features including tempo, stress, pitch, and tempo). As far as non-native speakers are concerned, accent refers to the break-down of the phonology of the native language into the L2 (Lippi-Green, 1998).

When students are learning an L2 they need to know that there are common judgments and attitudes which can be biased. "Apart from sign language it is as impossible to speak without an accent as it is to speak without making any sound" (Stockwell, 2002). Therefore, professors must include activities in which students can realize that they cannot deny the existence of an accent in their speech and in that of others. Students should avoid stigmatizing accents as something negative when learning a second language or when socializing.

Since every speaker is considered to have an accent, and different accents can exist for any given language, speakers of other languages will be inclined to imitate the variant associated with greater prestige. For example, a well-known misconception is that British English is the most prestigious variety of English; likewise, Spanish as spoken in Spain is considered by some as the most prestigious of Spanish dialects. In Stockwell's words, "[a]ccents and dialects that are geographically close to one another tend to be similar in form; gradually varying the further you travel away from them" (Stockwell, 2002).

According to Derwing (2003), despite extensive studies on the aspects of accent, a majority of them have dealt with questions such as age of acquisition and intelligibility. According to Sifakis and Sougari, (2005), very few studies have focused on the perceptions of non-native English speakers concerning pronunciation. Elaborating on the significance of the research on pronunciation in the context of ELT, Derwing (2003) asserts that grasping the interconnection between L2, accent, and social factors can help L2 learners to be more realistic in their goals (Derwing, 2003), leading to more efficient instruction of L2 teaching. In their studies, Majanen (2008), Yoshizawa (2010), and Sifakis and Sougari, (2005) conclude that more studies need to be conducted in contexts where English is learned as a foreign language with concentration on the attitudes towards pronunciation among non-native speakers in the Expanding Circle.

Prior to the $1960 \mathrm{~s}$, the dominant view regarding the instruction of pronunciation was based on the assertion that L2 learners need to strive to achieve native-like pronunciation (Bian, 2009). Based on this paradigm, the learners of an L2 should look at the native speaker as a criterion for intelligibility. This view poses multiple challenges and issues for the L2 learners. That is, this minority sets a hypothetical target group of speakers whose speaking accent and performance are used as the ultimate yardstick for correct accent (Majanen, 2008). Furthermore, enhancing the impression of the "infallible native speaker" reflects L2 learning as an endless elusive search for native speaker competence (Pavlenko,
2003), implying that the L2 learners are somehow "at fault" when they fail to fully learn a foreign language (Marx, 2002).

Many studies have concluded that there is a tendency to negatively assess accented speech compared to the standard accent both in the case of a native and non-native audience. The studies conducted by Brennan and Brennan (1981a, 1981b), Nesdale and Rooney (1996) and Sato (1998) showed similar results. These studies focused on how native speakers assessed the accented speech. The investigations carried out by Riches and Foddy (1989) and Derwing (2003) examined the idea of accent as an indicator of status. Based on the findings of these studies, the evaluative and prejudicial view of accented speech acts as a barrier in communication. However, it does not pose any serious challenges to mutual intelligibility, only giving a false impression of speaker based on his/her accent.

Prospective teachers start their teacher preparation programs with perceived knowledge and images of teaching based on their own previous experiences and observations of learning. Until 1970s, the investigations related to teachers only focused on teachers' behavior and regardless of their mental processes (Freeman, 2002). These studies were not satisfactory because they did not answer some of the major questions pertinent to the act and process of teaching. Thus, in an attempt to better understand teaching, studies began to focus on the ways teacher's beliefs were shaped and consequently influenced their classroom practices (Pajares, 1992). In other words, teaching is currently seen as synonymous with the way teachers think in order to make decisions regarding their teaching practices and, thus, they are viewed as active participants who decide what should go on in their classrooms.

The study of teacher beliefs is not something new. A large number of studies view beliefs as part of the episodic memory based upon personal experiences (e.g. Lunderberg \& Levin, 2004; Nespor, 1987; Richardson, 2003). While beliefs and knowledge are closely related, beliefs seem to be more subjective and personal, and usually reflect individual judgment and interpretation of the knowledge a community of people agree upon (Lunderberg \& Levin, 2004). Research suggests that the belief of teachers serve as filters for interpreting knowledge and experiences, guiding their decision making and influencing their actions in the classroom (Clandnin \& Connelly, 1987; Elbaz, 1981; Larsson, 1987). Studies on teacher beliefs have shown that teacher beliefs can have a profound impact on instructional decisions (Borg, 1998, 2003; Farrell \& Lim, 2005). As Pajares (1992) states, investigation into teachers' beliefs is important since "beliefs are the best indicators of the decisions individuals make throughout their lives" (p. 307).

A review of the previous studies in the Iranian context of ELT (e.g. Pourhosein, Gilakjani, 2012; Pishghadam \& Sabouri, 2011; Solhi \& Rahimi, 2013) indicated that, to date, to the best of the researcher's knowledge, no study has attempted to examine the perceptions Iranian EFL teachers hold towards their accent. In fact, given the way in which accent is perceived in ELT and in pronunciation teaching as well as due to the marginalization of pronunciation study in the field of applied linguistics, L2 instructors usually rely 
on their own intuitions with little effectiveness (Derwing \& Munro, 2005). Such kind of research can shed light on the contributions accent can make to ELT.

\section{Research Questions}

In line with the objectives of the study, the hereunder research questions were formulated:

Q1: What are the Iranian EFL teachers' perceptions of learning accent?

Q2: What are the Iranian teachers' perceptions of their foreign accent?

Q3: What are the Iranian teachers' perceptions of strategies of learning accent?

\section{METHOD}

\section{Research Design}

The overall design of this research study was mixed methods since both qualitative and quantitative data were collected and analyzed. Creswell (2009) stated, "[Quantitative] research is an inquiry approach useful for describing trends and explaining the relationship among variables found in the literature" (p. 58). The use of instruments to gather data is necessary in order to answer questions and to analyze results using statistics. "Survey designs are procedures in quantitative research in which investigators administer a survey or questionnaire to a sample or to an entire population of people in order to describe the attitudes, opinions, behaviors, or characteristics of the population" (Creswell, 2009, p. 60). The researcher decided to use a qualitative approach in this study too because this approach enabled him to obtain a closer perspective and deeper understanding about the participants' experiences. Merriam (1998) states that "the investigator is the primary instrument for gathering and analysing data and as such can respond to the situation by maximizing opportunities for collecting and producing meaningful information" (p. 20). Therefore, the researcher decided to use a qualitative approach to gain in-depth information useful for his study. In addition, a qualitative approach allowed the researcher to be physically present in the setting. The researcher also adopted the stance of a participant observer during the study. Creswell (2009) described the stance as allowing "the researcher to record information as it occurred" (p.179). In this study, the qualitative data were collected through semi-structured interviews.

\section{Setting and Participants}

Due to the quantitative and qualitative type of the study, the participants of this study consisted of 50 English teachers of English institutes in Hormozgan who ranged between 25 and 36 years old. There were 25 male and 25 female teachers. All of the teachers had over three years of teaching experience in different levels. The researcher used stratified random sampling technique for choosing participants for the quantitative part of the study. He used purposive sampling technique for the qualitative part of the study or the interview since he as- sumed that the opinions gathered from the selected group for the interviews represented the opinions of the whole group.

\section{Instruments}

The researcher used a questionnaire and semi- structured interviews in this study a description of which follows:

\section{Teachers'perceptions of accent questionnaire}

The questionnaire used in the present study was designed by the author based on the sample questions used by Derwing and Rossiter (2002). The questionnaire consisted of 30 items and was based on a 5-level Likert scale (1: strongly agree.5: strongly disagree). It included six general questions to collect demographic data of the participants. From among the 30 items, ten questions (1-10) assessed teachers' perceptions of learning accent, ten questions (11-20) measured teachers' perceptions of their foreign accent and ten questions (21-30) were about teachers' perceptions of strategies of learning accent. Moreover, there were three open ended questions. The general questions about the participants were not considered in the data analysis and interpretation; however, they can be used in a different study to find out whether teachers' native language, the age they started learning English, and the number of years they have been teaching English may have had any effects on their accent. Since reliability is sample dependent, the researcher piloted the questionnaire on 30 participants having similar characteristics to the main participants of the study and run Cronbach's alpha on the results. The Cronbach's Alpha reliability quotient gained was above 0.70 and was, therefore, deemed satisfactory (Brown, 2007).

\section{Semi-structured interviews}

Semi-structured interviews were also conducted with 10 teachers for the purposes of this study. A set of eight semi-structured interview questions was used to interview 10 teachers. In order to report the results of the interviews, the researcher used the exploratory content analysis approach recommended by Auerback and Silverstein (2003). Each interview session lasted about 10 minutes and a voice recorder was used to collect the interview contents. The semi-structured interviews were conducted to verify the results of the questionnaires employed in this study. The difference between a semi-structured and a structured interview lies in the fact that, while a structured interview holds a rigorous format and offers tight control of the responses, in a semi-structured interview the respondents are allowed more opportunity to express their ideas and, consequently, more issues relevant to the topic are brought up in the interview. The main purpose of using structured interviews and semi-structured ones is the triangulation possibilities that these two methods offer the researcher (Richards \& Schmidt, 2002).

The researcher interviewed each teacher individually in order to gather information on the topics that concerned personal qualities or negative feelings of teachers about their perceptions of learning accent. The interviews were conducted with the teachers individually to follow up their responses 
to the questionnaire and each interview lasted about ten to fifteen minutes. Moreover, the questions for the interview were related to the research questions and were content validated drawing on expert opinion in line with Brown (2007) by three EFL university professors.

\section{Data Collection Procedure}

The participants who met the criteria in the participants section were contacted by the researcher. A brief introduction concerning the aims of the study and data collection was given to them. Then the questionnaire was given to the participants. It should be mentioned that before distributing the questionnaire among the participants, it was piloted to establish its reliability. Then, the piloted questionnaire was administered to the convenient sample of fifty EFL teachers in some language institutes in Hormozgan. The questionnaire was handed in to the teachers participating in the study in their institutes. Due to the long length of the questionnaire, the teachers were asked to fill them at home and return them within a week.

When the quantitative phase was completed, the qualitative phase started. To this aim, a sample of ten teachers participated in the interviews. They were interviewed about their perceptions of learning accent, their perceptions of their foreign accent, and their perceptions of strategies of learning accent. The interviews took place in the institutes in which the teachers were teaching. The interviews were all audio -taped and later transcribed. Data from the interviews were analyzed qualitatively and described according to the main interview questions and presented as statements of the teachers' responses to the questions.

\section{Data Analysis}

The data collected from the questionnaire were imported and analyzed using SPSS (version 21.0) package. Frequency means and standard deviation (SD) were utilized to report descriptive data. Frequency distributions were used to measure how often certain scores occured (Salkind, 2008). In addition, mean as "the sum of all the values in a group, divided by the number of values in that group" (Salkind, 2008, p.20) and SD as "the average amount of variability in a set of scores" (Salkind, 2008, p.37) were also reported.

The qualitative data were analyzed using interpretive qualitative approach (Glesne, 1998).Within this paradigm, "it is possible to understand the subjective meaning of action (grasping the actor's beliefs, desires and so on) yet do so in an objective manner" (Schwandt, 2000, P.193). To do so, exploratory content analysis procedures were adopted. According to Neuman (1997) exploratory content analysis:

Lets a researcher reveal the content (i.e. messages, meanings, symbols) in a source of communication (i.e. a book, article, and movie). It lets him or her probe into and discover content in a different way from the ordinary way of reading a book or watching a television program. With content analysis, a researcher can compare content across many texts and analyze it with quantitative techniques (e.g. charts, tables). In addition, he or she can reveal aspects of the text's content that are difficult to see (p. 273).
Accordingly, first all the interview contents were previewed to get an idea of how the teachers had responded to the interview questions. Next, each interviewees' responses were carefully analyzed and the initial codes were identified. Through more analysis the initial codes were turned into themes and finally themes were reviewed several times to remove any source of ambiguities and errors. Finally, themes were labeled, described and reported.

\section{RESULTS}

\section{Characteristics of Teachers}

Before starting the main analyses, it was more sensible to know more about the characteristics of the teachers who were supposed to reveal their attitude towards accent. In this way, it is possible to find more explanations for the obtained results and its generalizability. Table 1 shows the general characteristics of teachers.

In terms of gender, 25 teachers were male and 25 were female and therefore, the present study is equally affected by male and female perspectives. In terms of age, 22 teachers were between 25-27, 16 teachers were between 28-30, 8 teachers were between 31-33, and 4 teachers were between 34-36 years old. In terms of academic degree 23 teachers had bachelor degree, and 27 had master degrees. In terms of first language, 47 teachers were native Farsi speakers, 2 teachers were native Arabic speakers, 1 teacher was native Turkish speaker. In terms of the age teachers started learning English, 6 teachers started between 4-8, 22 teachers started between 9-13, 14 teachers started between 14-18, and 8 teachers started when they were above 19 years old. In terms of teaching experience, 28 teachers had 3-5 years of experience, 12 had 6-8 years, 7 had 9-11 years, and 3 had 12-14 years of experience. In terms of a second language other than English, 9 teachers could speak another extra language and 41 teachers could not speak any other language except their native and English languages. Therefore, the dominant teachers were between 25-27 years old, were native Farsi speakers, started learning English when they were 9-13 years old, had teaching experience of 3-5 years and could not speak any other language other than native and English languages.

\section{Reliability of the Scale}

Another issue was the reliability of the instrument which was measured through internal consistency measure of Cronbach's Alpha. Table 2 shows the descriptive statistics of the pilot sample on data obtained by administering the Teachers' Perceptions of Accent Questionnaire.

As seen in Table 2, the pilot sample had a mean score of 83.42 ( $\mathrm{SD}=11.10$ ) and a reliability index of 0.67 which is considered acceptable due to the fact that it was in the pilot stage.

\section{Answering the First Research Question}

The first research question of the study was about the Iranian EFL teachers' perceptions of learning accent. As stated in Chapter Three, teachers' opinions in this regard were collect- 
Table 1. Main characteristics of teachers

\begin{tabular}{|c|c|c|c|c|}
\hline Main characteristics of teachers & Frequency & Percent & Valid percent & Cumulative percent \\
\hline \multicolumn{5}{|l|}{ Sex } \\
\hline Male & 25 & 50 & 50 & 50 \\
\hline Female & 25 & 50 & 50 & 100.0 \\
\hline \multicolumn{5}{|l|}{ Age } \\
\hline $25-27$ & 22 & 44 & 44 & 44 \\
\hline $28-30$ & 16 & 32 & 32 & 76 \\
\hline $31-33$ & 8 & 16 & 16 & 92 \\
\hline $34-36$ & 4 & 8 & 8 & 100.0 \\
\hline \multicolumn{5}{|l|}{ Academic degree } \\
\hline Bachelor & 23 & 46 & 46 & 46 \\
\hline Master & 27 & 54 & 54 & 100.0 \\
\hline \multicolumn{5}{|l|}{ First language } \\
\hline Farsi & 47 & 94 & 94 & 94 \\
\hline Arabic & 2 & 4 & 4 & 98 \\
\hline Turkish & 1 & 2 & 2 & 100.0 \\
\hline \multicolumn{5}{|l|}{ Age of learning English } \\
\hline $4-8$ & 6 & 12 & 12 & 12 \\
\hline $9-13$ & 22 & 44 & 44 & 56 \\
\hline $14-18$ & 14 & 28 & 28 & 84 \\
\hline Above 19 & 8 & 16 & 16 & 100.0 \\
\hline \multicolumn{5}{|l|}{ Years of teaching } \\
\hline $3-5$ & 28 & 56 & 56 & 56 \\
\hline $6-8$ & 12 & 24 & 24 & 80 \\
\hline $9-11$ & 7 & 14 & 14 & 94 \\
\hline $12-14$ & 3 & 6 & 6 & 100.0 \\
\hline \multicolumn{5}{|l|}{ Any second language } \\
\hline Yes & 9 & 18 & 18 & 18 \\
\hline No & 41 & 82 & 82 & 100.0 \\
\hline
\end{tabular}

Table 2. The descriptive statistics and Cronbach's alpha of teachers' perceptions of accent questionnaire

\begin{tabular}{lccccc}
\hline Mean & Variance & Standard deviation & Cronbach's alpha & $\begin{array}{c}\text { Cronbach's alpha based } \\
\text { on standardized items }\end{array}$ & $\begin{array}{c}\text { Number of } \\
\text { items }\end{array}$ \\
\hline 83.4211 & 123.368 & 11.10713 & 0.673 & 0.661 & 30 \\
\hline
\end{tabular}

ed through questionnaire and interview. Based on teachers' responses to each item of the questionnaire, percentage of teachers' responses to each item were calculated and formed the basis for judgment for their perspectives on accent. Table 3 shows the percentage of teachers' responses to each item of the questionnaire.

The first conclusion regarding Iranian teachers' perspective toward accent is that accent is considered an important part of language learning. As seen in Table 3 all the responses to the items of the questionnaire show that teachers care about learning accent and they considered it valuable and important. The strong value attached to accent can be clearly shown by teachers' responses to items \#5, 6, 8, and 9. For instance, in response to the item learning accent is as important as learning other language skills $24 \%$ of teachers strong- ly agreed and $40 \%$ agreed or in response to the item having a native-like accent has a great effect on social life $18 \%$ strongly agreed and $40 \%$ agreed. Similarly $22 \%$ of teachers strongly agreed with the statement, People will respect me more if I speak English with a nice accent and $46 \%$ agreed. Another conclusion is that Iranian EFL teachers have more tendency and inclination towards native English accent and having a native like accent is considered important and valuable. Therefore, they don't seems to be very positive towards non-English accent known as foreign accent. For instance, $42 \%$ of teachers strongly agreed and $44 \%$ agreed with the statement It is important for me to sound like a native English speaker which clearly convey the message that there is strong sensitiveness towards accent and sounding like native speaker is a concern. 
Table 3. Percentage of teachers' responses to each item of teachers' perceptions of accent questionnaire each item of the questionnaire

\begin{tabular}{|c|c|c|c|c|c|}
\hline & $\begin{array}{l}\text { Strongly } \\
\text { agree }(\%)\end{array}$ & Agree (\%) & Neutral (\%) & Disagree (\%) & $\begin{array}{c}\text { Strongly } \\
\text { disagree }(\%)\end{array}$ \\
\hline 1. Learning accent is an innate ability. & 8.0 & 28.0 & 20.0 & 32.0 & 12.0 \\
\hline 2. Learning an accent is completely impossible. & 2.0 & 4.0 & 2.0 & 24.0 & 68.0 \\
\hline $\begin{array}{l}\text { 3. I do not like to have native-like accent because } \\
\text { my non-native accent shows my identity. }\end{array}$ & 4.0 & 10.0 & 10.0 & 26.0 & 50.0 \\
\hline $\begin{array}{l}\text { 4. I prefer to communicate well rather than to } \\
\text { have a native-like accent. }\end{array}$ & 18.0 & 42.0 & 10.0 & 26.0 & 4.0 \\
\hline $\begin{array}{l}\text { 5. Learning accent is as important as learning } \\
\text { other language skills. }\end{array}$ & 24.0 & 40.0 & 12.0 & 24.0 & 0.0 \\
\hline $\begin{array}{l}\text { 6. It is important for me to sound like a native } \\
\text { English speaker. }\end{array}$ & 42.0 & 44.0 & 2.0 & 10.0 & 2.0 \\
\hline $\begin{array}{l}\text { 7. When I am speaking to another non-native } \\
\text { speaker, it is important for me that he or she has } \\
\text { a native-like accent. }\end{array}$ & 12.0 & 24.0 & 24.0 & 34.0 & 6.0 \\
\hline $\begin{array}{l}\text { 8. Having a native-like accent has a great effect } \\
\text { on social life. }\end{array}$ & 18.0 & 40.0 & 26.0 & 14.0 & 2.0 \\
\hline $\begin{array}{l}\text { 9. People will respect me more if I speak English } \\
\text { with a nice accent. }\end{array}$ & 22.0 & 46.0 & 12.0 & 18.0 & 2.0 \\
\hline $\begin{array}{l}\text { 10. Accent plays a role in my communication } \\
\text { problems. }\end{array}$ & 10.0 & 28.0 & 24.0 & 34.0 & 4.0 \\
\hline $\begin{array}{l}\text { 11. When I speak English, I have a foreign } \\
\text { accent (non-native accent) to some degree. }\end{array}$ & 4.0 & 54.0 & 24.0 & 12.0 & 6.0 \\
\hline $\begin{array}{l}\text { 12. It is difficult for people to understand my } \\
\text { accent. }\end{array}$ & 0.0 & 6.0 & 22.0 & 44.0 & 28.0 \\
\hline $\begin{array}{l}\text { 13. It is not possible for adults to acquire a native } \\
\text { accent. }\end{array}$ & 8.0 & 20.0 & 10.0 & 48.0 & 14.0 \\
\hline $\begin{array}{l}\text { 14. Motivation has a great effect on accent } \\
\text { improvement. }\end{array}$ & 56.0 & 30.0 & 10.0 & 2.0 & 2.0 \\
\hline $\begin{array}{l}\text { 15. Gender affects the degree of accent and } \\
\text { women can acquire native-like accent better than } \\
\text { men. }\end{array}$ & 4.0 & 14.0 & 26.0 & 28.0 & 28.0 \\
\hline $\begin{array}{l}\text { 16. The amount of L1 (first language) use affects } \\
\text { the use of foreign accent (non-native accent). }\end{array}$ & 14.0 & 40.0 & 22.0 & 18.0 & 6.0 \\
\hline $\begin{array}{l}\text { 17. I have problem with phonological differences } \\
\text { between Persian and English. }\end{array}$ & 2.0 & 22.0 & 14.0 & 52.0 & 10.0 \\
\hline $\begin{array}{l}\text { 18. My first language has a great effect on my } \\
\text { English accent. }\end{array}$ & 12.0 & 26.0 & 14.0 & 34.0 & 14.0 \\
\hline $\begin{array}{l}\text { 19. I feel insecure and unconfident about my } \\
\text { foreign accent. }\end{array}$ & 2.0 & 8.0 & 14.0 & 56.0 & 20.0 \\
\hline $\begin{array}{l}\text { 20. I sometimes feel embarrassed about my } \\
\text { foreign accent when I speak with a native or } \\
\text { native-like speaker. }\end{array}$ & 4.0 & 22.0 & 10.0 & 36.0 & 28.0 \\
\hline $\begin{array}{l}\text { 21. I listen to authentic language as much as } \\
\text { possible: for example, I listen to tapes/television/ } \\
\text { music/movies. }\end{array}$ & 46.0 & 38.0 & 2.0 & 12.0 & 2.0 \\
\hline 22. I try to understand pronunciation rules. & 48.0 & 46.0 & 2.0 & 0.0 & 4.0 \\
\hline $\begin{array}{l}\text { 23. I pay attention to my accent when I am } \\
\text { talking. }\end{array}$ & 40.8 & 32.7 & 16.3 & 10.2 & 100.0 \\
\hline $\begin{array}{l}\text { 24. I notice people's mouth movement when } \\
\text { they are speaking in English. }\end{array}$ & 16.0 & 38.0 & 16.0 & 20.0 & 10.0 \\
\hline
\end{tabular}


Table 3. (Continued)

\begin{tabular}{|c|c|c|c|c|c|}
\hline & $\begin{array}{c}\text { Strongly } \\
\text { agree }(\%)\end{array}$ & Agree (\%) & Neutral (\%) & Disagree (\%) & $\begin{array}{c}\text { Strongly } \\
\text { disagree }(\%)\end{array}$ \\
\hline $\begin{array}{l}\text { 25. I write down the pronunciation of words in } \\
\text { English (using phonetic symbols) }\end{array}$ & 16.0 & 40.0 & 4.0 & 28.0 & 12.0 \\
\hline $\begin{array}{l}\text { 26. I try to get the melody of the language by } \\
\text { listening to songs and singing them so that I can } \\
\text { memorize a lot of phrases. }\end{array}$ & 24.0 & 44.0 & 14.0 & 18.0 & 0.0 \\
\hline $\begin{array}{l}\text { 27. When I am listening, I try to identify how } \\
\text { people's accent is different to my own. }\end{array}$ & 34.0 & 46.0 & 6.0 & 14.0 & 0.0 \\
\hline $\begin{array}{l}\text { 28. I never miss the chance to speak to native } \\
\text { speakers. }\end{array}$ & 34.0 & 38.0 & 16.0 & 12.0 & 0.0 \\
\hline $\begin{array}{l}\text { 29. I record my speaking in order to be aware of } \\
\text { my accent errors. }\end{array}$ & 12.0 & 32.0 & 10.0 & 28.0 & 18.0 \\
\hline $\begin{array}{l}\text { 30. I do accent role models. For example, I } \\
\text { imitate a native speaker whom I admire or a } \\
\text { person who has a native-like accent. }\end{array}$ & 34.0 & 32.0 & 6.0 & 20.0 & 8.0 \\
\hline
\end{tabular}

Teachers' responses to interview questions also led to the same conclusion that accent is considered important and valuable to Iranian EFL teachers. In response to the question Do you think learning accent is important? Some of the responses are as follows:

Interviewee 1: Well, I think learning accent is important you know I believe that someone who learns English is learning a skill in his life and learning the accent of English could be another skill which could help that person in many situations so, learning accent is very important.

Interviewee 2: Of course I think it's important for everyone to learn accent to speak that language - I mean the second language - better, but in my idea you know, without learning accent very good you can speak, you can communicate with others, but it's better to learn accent Interviewee 9: Yes, of course. I think if you want to master a language well and speak it nice, we have to learn the accent of that language too.

In the follow up question how important is learning accent to you? Some of the responses are as follows:

Interviewee 9: On scale of one to five, I think four would be the right criteria that describes my interest and importance that I give to it.

Interviewee 1: As I said it's very important to me.

Interviewee 3: For me I think accent is really important and I can say even it's the most important thing in English for me at this time. And I really like to have a native-like accent.

The above quotations show that accent and learning accent is considered highly positive and important. In above quotation such phrase like very important or really important clearly shows the intensity and degree of importance of accent.

\section{Answering the Second Research Question}

The second research question was about Iranian teachers' perceptions of their foreign accent. As partly answered in the previous section, teachers don't seems to be happy with foreign accent and are more in favor of native like accent. However, an important finding was that though teachers aspired for native like accent, they did not seem to suffer from their non-native like accent which is a signal of strong self-identity. For instance, in the items \# 19 and 20 this issue is better captured. For instance, in response to the item \#19 I feel insecure and unconfident about my foreign accent $56 \%$ of teachers disagreed and $20 \%$ strongly disagreed. Similarly, with regard to statement $I$ sometimes feel embarrassed about my foreign accent when I speak with a native or native-like speaker $36 \%$ of teachers disagree and $28 \%$ of teachers strongly disagreed. Moreover, they believed their current accent was $\mathrm{OK}$ and other people could easily understand them. For instance in response to the statement It is difficult for people to understand my accent $44 \%$ of teachers disagreed and $28 \%$ strongly disagreed.

The analysis of the data obtained from interviews indicated that teachers' foreign accent was considered as a sign of Iranian identity and native English speakers could easily notice it. What follows are some of the teachers' responses to the interviewer question Do you agree that your foreign accent shows your identity?

Interviewee 1: All right, yeah, I agree. It definitely shows your identity. Just imagine people for example from India when they go to other countries, they start speaking so everybody knows that they are from India and that's just because of their accent or again when Iranian go to other countries as soon as we open our mouths to speak English people recognize that we're not from I don't know that country for example America, because of the foreign accent that we have so our foreign accent definitely shows our identity.

Interviewee 2: Ok, yeah I do agree with this, I mean when you speak English, of course me, when I speak English I know that others know I'm not a native, so it can be a kind of my identity, and I like that, why not? I'm Iranian, and when I speak English maybe some other 
people understand that I'm not British or American, so I'm Iranian and it's not bad.

Interviewee 8: Totally, I agree. Yes, sure. Foreign language doesn't show anything except the foreign accent. Actually, it shows that where you come from. How did you learn? You learned it differently compared with your mother language.

Following the answers to the above question, the researcher asked Is the issue of identity important to you. Teachers answered:

Interviewee 6: Yes the issue of accent is important to me because you know! You don't want to seem, you don't want your identity to be shown to others, I don't know maybe in the future you would like to teach English in an another country so at the beginning I don't want to have Iranian accent to be recognized as an Iranian.

Interviewee 1: If you mean while I'm speaking English is identity important to me or not? I would say "not at all". It's not important and I believe that you know speaking English with a nice accent can help you in many cases and can make you, you know successful in your communication so why shouldn't I follow it and I guess by speaking English like I mean native speakers, you can make more effective communication so, identity here is not important to me.

Interviewee 7: Well, it is somehow important because American or British people who speak English with native accent feel more comfortable with their own countrymen. So, of course they treat you differently with others, but if you speak with a nice native accent, they would feel more comfortable with you and they would treat you like their own countrymen.

As seen in the above quotations teachers do not seem to care about their native identity and they preferred to sound like native speakers. One teacher even explicitly stated that he prefers to hide his identity and prefers not to be recognized as Iranian. Teachers also believed that they have foreign accent in their English speaking. Following quotations are teachers responses to the question Do you think that you have a foreign accent to some degree?

Interviewee 8: I suppose. Because it's really hard to hide your foreign accent, especially for people who live in a place that we speak our mother language every day. Even if I've been the best one who speaks English perfectly, I still have a little foreign accent

Interviewee 3: Yeah. Unfortunately I have foreign accent and... but I'm trying to learn native like accent.

Interviewee 7: Well, of course, everyone who is not native English speaker has some foreign accent and also I'm a person who has grown up in a Persian society, a society that everyone speaks Persian, so I also have a non-native accent to some degree.

\section{Answering the Third Research Question}

The third research question was about Iranian teachers' perceptions of strategies of learning accent. In this regards, teachers' opinions were partly elicited through certain items of Teachers' Perceptions of Accent Questionnaire. Teachers' agreement or disagreement with some strategies to improve their accent were addressed by items 21 to 30 . These strategies were as follows:

- I listen to authentic language as much as possible: for example, I listen to tapes/television/music/movies.

- I try to understand pronunciation rules.

- I pay attention to my accent when I am talking.

- I notice people's mouth movement when they are speaking in English.

- I write down the pronunciation of words in English(using phonetic symbols)

- $\quad$ I try to get the melody of the language by listening to songs and singing them so that I can memorize a lot of phrases.

- When I am listening, I try to identify how people's accent is different to my own.

- I never miss the chance to speak to native speakers.

- I record my speaking in order to be aware of my accent errors.

- I do accent role models. For example, I imitate a native speaker whom I admire or a person who has a native-like accent.

Teachers' responses to the Teachers' Perceptions of Accent Questionnaire indicated that teachers on the whole were positive with above strategies to improve accent. Among the above strategies, strategies of listening to authentic language, understanding pronunciation rules, and comparing people's accent with their own accent were among the most favorable strategies to improve accent.

This issue was also addressed by teachers' responses to the interview questions too. Teachers' answers to the interview questions indicated that teachers use variety of techniques to improve their accent. For instance, they mentioned such techniques like, watching English movies, noticing stress, and pronunciation patterns, imitating, speaking with native people, using books, and recording and monitoring their speech. Following quotations are some of the answers to the questions what have you done to improve your accent? and what other strategies do you recommend for improving accent?

Interviewee 3: I've studied some books. I mean American accent book. And I've watched some movies with native accent and I've talked with some native speakers. I mean on online chatting and speaking with them, just this.

Interviewee 6: Well, watching films, and listening to music and trying to imitate the way that they speak would have some kind of effect on your own accent.

Interviewee 7: Well, in my opinion, listening is one the most important things that helps you to learn accent. Because when you listen to news or watch movies, you see how they talk to each other and learn their culture, so it will automatically stay in your minds, and it will become one of your instincts, and you will speak English with a right accent.

Interviewee 9: I try to check the pronunciation of every new word that I learn, and I try to listen to that pronunciation and imitate it and also paying attention to the pronunciation of native speakers and movies and songs. 
Interviewee 8: Umm. Imitating. So far since I was a kid until now, I've tried to listen to English people with different languages and accents and imitate them, repeat after them, do like them, act like them, even using body language, their eyes, how they move their hands and try to do my best to change the tone of my voice and speak like them.

Interviewee 1: Since I started learning English, learning accent was very important to me. I mean I was so motivated in speaking English with nice American accent and I always try to write the phonetic of words, pay attention to the stress of words, intonation of sentences, these things and record my sound and my voice and listen to it and try to eliminate my problems. Yeah, these are the things that I've done to improve my accent.

\section{DISCUSSION}

The present study aimed at exploring Iranian EFL teachers' perceptions of accent and the way they view their English accent and the strategies they employ to improve it. Teachers were dominantly between 25-27 years old, were native Farsi speakers, and started learning English when they were 9-13 years old, had teaching experience of 3-5 years and could not speak any other language other than native and English languages. Their opinions and comments with regard to English accent were gathered through questionnaires and interviews. Based on the analysis performed on the data collected through questionnaires and interviews it was found that teachers care about learning accent and they considered it valuable and important. They admitted they have foreign accent to some degree and they did not seem to be happy with foreign accent and were more in favor of native like accent. Regarding the strategies to improve English accent, they mentioned techniques like listening to authentic language, understanding pronunciation rules, and comparing people's accent with their own accent, watching English movies, noticing stress, and pronunciation patterns, imitating, speaking with native people, using books, and recording and monitoring their speech.

Regarding the positive attitude toward native accent and negative attitude toward foreign accent the results of the study is in line with the ones by Brennan and Brennan (1981a, 1981b), Nesdale and Rooney (1996), Riches and Foddy (1989) and Derwing (2003). The findings of present study is also in line with the study by Pishghadam and Sabouri (2011) on EFL learners participants. Pishghadam and Sabouri's quantitative study (2011) of 165 Iranian English learners, ranging from 18 to 30, investigated their attitudes towards different varieties of English in relation to the perspective of the theory of "World Englishes" using a modification of the matched guise technique. The researchers found that the study's participants believed that American accent is quite superior to the other accents of English. Participants also thought that people with American accent are better teachers. The researchers argue that these results reveal "the fact that Iranian English learners still believe in the existence of one real English rather than varieties of English.

In non-Iranian context Friedrich (2000) investigated the attitudes of 190 Brazilian EFL learners, ranging from 18 to 40, towards English language. The purpose of the study was to examine the relationship between the attitudes and expectations and "the circumstances of both the learning and the sociolinguistic reality of English in Brazil” (p. 216). The results of the study indicated that although only a few of respondents learned British English, the majority of them considered American English as the sole variety of English they were learning. Also, most of the learners in the Friedrich study reported that they considered American English as more prestigious, intelligible and suitable than other varieties of English.

Iranian EFL teachers' attitudes can also be explained through theoretical model of Kachru describing developmental process of spread of English. Kachru (1992) proposes a three-step process of the spread of English which seems to be more applicable to non-native institutionalized varieties of English. The first process is 'non-recognition' of the local variety, which is when the imported variety is thought to be superior to the local variety of English; hence, the transported variety will be selected as the model for language learning and teaching. The speakers of the local variety tend to speak the exonormative variety to be native-like. The second process is characterized by 'co-existence' of the local and the imported variety. At this stage, although the local variety is used alongside the transported variety, it is still considered to be inferior to the transported variety. Kachru calls the third and final process 'recognition'. During this stage, the local variety increases in prominence and becomes socially accepted and therefore the speakers of the local variety will strive to speak the local variety. It seems that Iranians are still in the second phase of the Kachru's model still believing in one ideal form of English.

The present study also showed that Iranian teachers did not care about their Iranian identity and some even mentioned their disposition to hide their Iranian identity when conversing with foreigners. This act of language teachers need to observe in real context to really make sure that Iranians do not care about their Iranian identity. Because there is a possibility what they have reported may not match the actual behaviors and their behaviors may be due to negative reactions to some sociological issues in the country. Another explanation can be put forward through Dornyei's (2005) theory of possible selves. Commenting on the salience and multifaceted composition of an integrative motivation factor in their data, Dornyei and Csizer (2002. P. 453) speculated that the process of identification theorized to underpin integrativeness might be better explained as an internal process of identification within the person's self-concept, rather than identification with an external reference group. Dornyei (2005) developed this speculation further by drawing on the psychological theory of 'possible selves'. According to this theory, possible selves represent individuals' ideas of 'what they might become, what they would like to become, and what they are afraid of becoming', and so 'provide a conceptual link between the self-concept and motivation' (Markus \& Nurius, 1987. P. 157). Norton (2000) argues that that SLA theorists have not developed a comprehensive theory of identity that integrates the language learner and the language learning context. She uses the term identity to reference how 
a person understands his or her relationship to the world, how that relationship is constructed across time and space, and how the person understands possibilities for the future. She also develops the motivational concept of 'investment' to capture the "socially and historically constructed relationship of learners to the target language, and their often ambivalent desire to learn and practice it' (Norton, 2000.p. 10). When learners invest in a language, they do so with the understanding that they will acquire a wider range of symbolic and material resources, which will enhance their cultural capital, their identity and their desires for the future.

\section{REFERENCES}

Abelson, R. (1979). Differences between belief system and knowledge systems. Cognitive Science, 3(4), 355-366.

Auerbach, C. F., \& Silverstein, L. B. (2003). Qualitative data: An Introduction to Coding and Analysis. New York: New York University Press.

Bian, Y. W. (2009). Chinese learners' identity in their attitudes towards English Pronunciation/accents. CELEA Journal, 32 (2), 66-74.

Borg, S. (1998a). Data-based teacher development. ELT Journal, 52(4), 273-81.

Borg, S. (1998b). Talking about grammar in the foreign language classroom. Language

Awareness, 7(4), 159-75.

Borg, S. (2003). Teacher cognition in language teaching: A review of research on what

language teachers think, know, believe, and do. Language Teaching, 36(1), 81-109.

Borg, M. (2008). Teaching post-CELTA: the interplay of novice teacher, course and context. In T, S, C. Farrell, (Ed.), Novice language teachers: Insights and perspectives for the first year (pp. 104-117). London: Equinox Publishing Ltd.

Borg, S. (2009). Introducing language teacher cognition. JACET Summer Seminar Proceedings Perspectives on Language Teacher Development, 8(1), 1-5. Retrieved January, 2016 form: URL-http://www.education.leeds. ac.uk

Boyd, S. (2003). 'Foreign-born teachers in the multilingual classroom in Sweden: The role of attitudes to foreign accent', International Journal of Bilingual Education and Bilingualism, 6(3), 283-295.

Brennan, E. M., \& Brennan, J. S. (1981a). Accent scaling and language attitudes: Reactions to Mexican American English speech. Language and Speech, 24(3), 207-221.

Brennan, E. M., \& Brennan, J. S. (1981b). Measurements of accent and attitude toward Mexican-American Speech. Journal of Psycholinguistic Research, 10(5), 487-501.

Brown H. D. (2007). Principles of language learning and teaching ( $5^{\text {th }}$ ed.). NY: Pearson Education.

Brown, H.D. (2007). Teaching by Principles: An interactive approach to language pedagogy ( $3^{\text {rd }}$ Ed.). Englewood Cliffs, NJ: Prentice Hall Regents.

Clandinin, J., \& Connelly, F. M. (1987). Teachers' personal knowledge: What counts aa'personal' in studies of the personal. Journal of Curriculum Studies, 19(5), 487-500.
Creswell, J. W. (2009). Research design: Qualitative, quantitative, and mixed methods approach. Los Angeles, CA: Sage Publications.

Derwing, T. M. (2003). What do ESL students say about their accents? The Canadian Modern Language Review, 59 (4), 547-566.

Derwing, M. T., \& Munro, M. J. (2005). Second Language Accent and Pronunciation Teaching: A Research-Based Approach. TESOL Quarterly, 39 (3), 379-397.

Derwing, T. M., \& Rossiter, M. J. (2002). ESL learner's perception of their pronunciation needs and strategies. System, 30(1), 155-166.

Donaghue, H. (2003). An Instrument to elicit teachers' belief and assumptions. ELT Journal, 57(4) October. Oxford University Press.

Dornyei, Z. (2005). The psychology of the language learner: Individual differences in language acquisition. Mahwah, New Jersey: Erlbaum.

Dörnyei, Z., \& Csizér, K. (2002). Some dynamics of language attitudes and motivation: Results of a longitudinal nationwide survey, in Applied Linguistics, 23(4), 421-62.

Elbaz, F. (1981). The teacher's "practical knowledge": Report of a case study. Curriculum Inquiry, 11(1), 43-71.

Farrell, T. S. C., \& Lim, P. C. P. (2005). Conceptions of grammar teaching: A case study of teachers' beliefs and classroom practices. TESL-EJ, 9(1), 1-13.

Farrell, T. S. C., \& Patricia, L. P. C. (2005). Conceptions of grammar teaching: A case study of Teachers' Beliefs and Classroom Practices. Teaching English as a second language-e-Journal, 9(2).

Freeman, D. (2002). The hidden side of the work: Teacher knowledge and learning how to teach. A perspective from North American educational research on teacher education in English language teaching. Language Teaching, 35(1), 1-13.

Friedrich, P. (2000). English in Brazil: Functionsand attitudes. World Englishes, 19(2), 215-223.

Glesne, C. (1998). Becoming qualitative researchers: an introduction. Longman.

Green, J. M. (1993). Student attitudes toward communicative and non-communicative activities: Do enjoyment and effectiveness go together? The Modern Language Journal, 77(1), 1-10.

Kagan, D. M. (1992). Implications of research on teacher belief. Educational Psychologist. 27(1), 65-90.

Kachru, B. B. (1992). The other tongue: English across cultures $\left(2^{\text {nd }}\right.$ ed). Urbana, IL: University of Illinois Press.

Larsson, E. (1987). Learning from experience: Teachers' conceptions of change in their professional practice. Curriculum Studies, 19(1), 35-43

Lippi-Green, R. (1998). English with an Accent: Language, ideology, and discrimination in the United States. London: Routledge.

Lunderberg, M. A. \& Levin, B. B. (2004). Prompting the development of preservice teachers' Beliefs through cases, action research, problem-based learning and technology, In J. Raths \& A. Mc Aninch (Eds.) Teacher beliefs and teacher education: Advances in teacher education, 6(1), 23-42. Greenwich, CT: Information Age Publishers. 
Majanen, S. (2008). English as a lingua franca: Teachers' Discourses on Accent and Identity.

[MA thesis.] Helsinki: University of Helsinki. Retrieved fromhttp://www.helsinki.fi/englanti/elfa/ProGradu_Silke_Majanen.pdf [18.12.2013]

Markus, H., \& Nurius, P. (1987) Possible selves: The interface between motivation and the self-concept. In K. Yardley and T. Honess (eds) Self and Identity: Psychosocial Perspectives (pp. 157_172). Chichester: John Wiley and Sons.

Marx, N. (2002). Never quite a 'native speaker': Accent and Identity in the L2 - and the L1.

Merriam, S. B. (1998). Qualitative research and case study applications in education. San Francisco: Jossey-Bass.

Munby, H. (1984). A qualitative approach to the study of a teacher's beliefs. Journal of Research in Science Teaching. 21(1), 27-38.

Nesdale, D., \& Rooney, R. (1996). Evaluations and stereotyping of accented speakers by pre-adolescent children. Journal of Language and Social Psychology, 15(1), 133-154.

Nespor, J. (1987). The role of beliefs in the practice of teaching. Journal of curriculum studies. 19(3), 317-328.

Neuman, W. N. (1997). Social research methods: qualitative and quantitative approaches. Boston: Allyn \& Bacon Publications.

Norton, B. (2000). Identity and Language Learning: Gender, Ethnicity and Educational Change. Harlow: Longman. The Canadian Modern Language Review, 59 (2), 264-281.

Pajares, M. (1992). Teachers' beliefs and educational research: Cleaning up a messy construct.

Pavlenko, A. (2003). "I never knew I was a bilingual": Reimagining Teacher Identities in TESOL. Journal of Language, Identity, and Education 2 (4), 251-268.

Pishghadam, R., \& Sabouri, F. (2011). A quantitative survey on Iranian English learners attitudes towards varieties of English: World English or world Englishes? English Language and Literature Studies, 1(1).

Piske, T. (2001). Factors affecting degree of foreign accent in an L2: a review. Journal of Phonetics, 29(2), 191-215.
Pourhosein Gilakjani, A. (2012). A study of factors affecting EFL learners' English

pronunciation learning and the strategies for the instruction. International Journal of Humanities and Social Science, 2(3).

Richardson, V. (2003). Preservice teachers' beliefs. In J. Raths \& A. McAninch (Eds.).Teacher beliefs and teacher education. Advances in teacher education (pp.1-22.).Greenwich, CT: Information Age Publishers.

Richards, J. C., \& Schmidt, R. (2002). Longman dictionary of language teaching and applied linguistics ( $3^{\text {rd }}$ ed.) UK: Pearson Education

Riches, P., \& Foddy, M. (1989). Ethnic accent as a status cue. Social Psychology Quarterly, 52 (3), 197-206.

Salkind, N. J. (2008). Statistics for people who hate statistics. Los Angeles: Sage Publications.

Sato, M. (1998). Constitution of form-orientation: Contributions of context and explicit knowledge to learning from recasts. Canadian Journal of Applied Linguistics 14.1, 1-28.

Schwandt, T. A. (2000). Three epistemological stances for qualitative inquiry: Interpretivism, hermeneutics and social constructivism. In N. K. Denzin \& Y. S. Lincoln (Eds.), Handbook of qualitative research $\left(2^{\text {nd }} \mathrm{ed}\right.$., pp. 189-214). Thousand Oaks, CA: Sage.

Sifakis, N. C., \& Sougari, A.-M. (2005). Pronunciation issues and EIL pedagogy in the periphery: A survey of Greek state school teachers' beliefs. TESOL Quarterly, 39(3), 467-488

Solhi, M., \& Rahimi, A. (2013). Self-perception of non-native speaker teacher of English in the expanding circle. International Research Journal of Applied and Basic Sciences, 4(4), 863-869.

Stockwell, P. (2002). Sociolinguistics: A Resource Book for Students. London: Routledge (3).

Yoshizawa, A. (2010). Learner identity construction in EFL context: Needs for research area expansion and examination of imagined identities in imagined communities. Retrieved from http://www.keiwa-c.ac.jp/kenkyu/kiyo/ doc/kiyo193.pdf [15.12.2013] 